\title{
Rasisme og diskriminering: komplekse begrep med mange innhold
}

\section{GUNNHILD VIST}

\begin{abstract}
I denne studien har ungdom formidlet forståelser av rasisme og diskriminering som noe likt og ulikt, komplekst og relasjonelt. Ungdommenes uttrykk og refleksjoner bidrar til å sette fokus på at debatter og videre forskning på disse temaene $i$ større grad bør tematisere at rasisme og diskriminering forstås svoert forskjellig. I tillegg kan det voere behov for å bringe inn aspekter knyttet til makt og anerkjennelse.
\end{abstract}

\section{Introduksjon}

"Det er et veldig vanskelig tema å sitte og snakke om, egentlig, å få noe klarhet $i$ « (Svein, gr. 1). Svein uttrykte dette i et fokusgruppeintervju knyttet til en studie hvor ungdommers forståelser av rasisme og diskriminering var tema. På ulike måter er rasisme og diskriminering blitt løftet fram i studier de siste årene (Høgmo 1998, OMOD 2006, Prieur 2004, Sollund 2007).

Gunnhild Vist, forsker III og prosjektmedarbeider, Høgskole- og universitetssosialkontor (HUSK), Mitt-Norge
Dette har vært studier hvor utgangspunktet har vært å undersøke personers erfaringer eller opplevelser knyttet til ulike aspekter ved deres liv, men hvor rasisme og diskriminering er blitt aktualisert og tematisert. I min studie har fokuset vært på forståelser av rasisme og diskriminering. For å få empirisk basert kunnskap om dette har jeg intervjuet ungdom i fokusgrupper. Jeg har ikke vært opptatt av ungdommenes tanker om årsaker til eller utbredelse av rasisme og diskriminering. Det er deres refleksjoner rundt ordene og fenomenene jeg har ønsket å innhente kunnskap om. Forstås rasisme og diskriminering som det 
samme, eller som noe forskjellig? Hvordan forstås det? Har begrepene samme betydning for norsk ungdom, som for ungdom med minoritetsbakgrunn? Forstås dette ulikt av hvit ungdom og svart ungdom? Denne artikkelen vil gi en presentasjon av forståelser som kom til uttrykk i studien, og et bilde av refleksjoner og tema som ble aktualisert.

Rasisme og diskriminering blir brukt av ulike aktører og på ulike måter til å forklare og forstå et stort spenn av fenomen og situasjoner. I norsk debatt råder det en uklarhet om hvordan rasismebegrepet bør forstås og brukes, og uenighet om hva som er en hensiktsmessig begrepsforståelse. ${ }^{2}$ Alvorlige hendelser har ofte utløst debatter om rasisme og diskriminering i Norge. De siste årene har særlig to episoder i det offentlige rom på nytt aktualisert debattene. I disse episodene var svarte menn, begge født i Afrika, i dramatiske møter med henholdsvis politi og ambulansepersonell. Fra ulike hold er det blitt stilt spørsmål om disse mennenes etnisitet var av betydning for måten de

1 Ordet svart assosieres i norsk språk ofte med noe negativt som skittent, ulovlig eller urent. Mange vegrer seg derfor mot å benevne mennesker med ikke hvit hud som svarte, og foretrekker innvandrerbegrepet, negerbegrepet eller "bindestreksbegrep« som norsk-pakistansk. Det kan knyttes en lang og interessant diskusjon til bruken av de ulike begrepene, noe denne artikkelen ikke har ramme til. I artikkelen velger jeg å bruke begrepene svart og hvit der jeg ser det er av betydning å benevne personers hudfarge som fenotypisk trekk.

2 Avisen Aftenposten løftet denne debatten på nytt våren 2008, www.aftenposten.no/debatt/ article2445917.ece. ble møtt. ${ }^{3}$ I debatter i kjølevannet av hendelsene er rasismebegrepet blitt brukt som om det har et entydig innhold. At begrepet forstås og brukes ulikt av ulike aktører i debatten, og av personer med ulike ståsted i samfunnet, er imidlertid i liten grad blitt løftet fram.

Også i den norske akademiske debatten er det et mangfold av ulike måter å forholde seg til begrepene rasisme og diskriminering på. Lien (1997a, 1997b) avviser rasismebegrepet, Høgmo (1998) "går forbi« rasismebegrepet og bruker diskrimineringsbegrepet, Gullestad $(2000$, 2002) bruker nesten utelukkende rasismebegrepet, mens Lunde (1997) bruker begrepene om hverandre. Dette er sentrale aktører i den akademiske debatten om rasismebegrepet, og "alle» er de enige om at det eksisterer en forvirring om hvordan begrepet skal brukes i norsk kontekst. Et sentralt, men ikke entydig omdreiningspunkt i debatten er om det er handlerens intensjon eller holdning, eller handlingens konsekvens som bør gis forrang i forståelsen av rasisme. På den ene siden argumenteres det for en smal forståelse av rasismebegrepet og for en begrenset bruk av ordet (Lien 1997a, 1997b, Brox 1991). Denne forståelsen møter motstand hos de som mener det er hensiktsmessig med en mer åpen og mindre presis begrepsforståelse og bruk (Gullestad 2002, Lunde 1997). Rasismebegrepet har generert debatter

3 Etter den siste av disse hendelsene ble det igangsatt en kartlegging vedrørende diskriminering av personer med innvandrerbakgrunn $\mathrm{i}$ offentlig sektor i Norge. Kartleggingen munnet ut i en rapport utgitt av Likestillings- og diskrimineringsombudet (LDO) i januar 2008. 
preget av sterk moralsk retorikk (Hagelund 2003, 2004, Fangen 1997). Hagelund (ibid.) stiller spørsmål om det er så vanskelig å snakke om rasisme fordi det oppfattes som et spørsmål om det gode mot det vonde.

\section{Metode}

Målet for studien har vært å få empirisk basert kunnskap om forståelser av begrepene rasisme og diskriminering, gjennom å intervjue ungdom. Fokusgruppeintervju utgjorde arenaer hvor jeg fikk tilgang til ungdommenes refleksjoner, meningsutvekslinger og uttrykk for forståelser av temaet. Jeg har intervjuet totalt 16 ungdommer i alderen 16-25 år, fordelt på fire fokusgrupper hvor det var tre til fem deltakere. ${ }^{4}$ Fokusgruppeintervjuene ble gjennomført i perioden mai - november 2006. Det var et ønske å rekruttere ungdom fra arenaer der "ungdom flest" befinner seg. Deltakerne i fokusgruppe 1 og 2 ble rekruttert ved kontakt med en videregående skole. Jeg fikk kontakt med deltakerne gjennom å presentere studien for elever i ulike klasser ved skolen. Deltakerne i gruppe 3 ble rekruttert $\mathrm{i}$ en vennekrets knyttet til to ulike ungdomsskoler. Selv om jeg gikk åpent ut i rekrutteringen av de tre første gruppene, ble disse bestående av hvite ungdommer. Dette kan forklares med at det trolig ikke var stor andel av ikke-hvite ungdommer ved de skolene deltakerne var rekruttert fra.

4 Ungdommene ble ikke spurt om alder. Deltakerne var elever på ungdomsskoler eller videregående skoler. Jeg antar at et par av deltakerne i gruppe 4 var passert 20 år.
Det var ikke-hvite ungdommer til stede i en av klassene hvor jeg informerte om studien, men disse meldte seg ikke til å delta i fokusgruppeintervju. For å få et mer mangfoldig utvalg tok jeg derfor kontakt med en videregående skole, hvor jeg antok at jeg ville nå ikke-hvit ungdom. Jeg fikk kontakt med en klasse som besto av ungdom med annen nasjonal bakgrunn og etnisk tilhørighet enn norsk. På samme måte som ved den første videregående skolen, informerte jeg om studien i klassen, og jeg fikk etablert en fjerde gruppe. ${ }^{5}$ Den åpne rekrutteringen har ivaretatt ungdommenes frivillighet til deltakelse.

Hvert fokusgruppeintervju varte i omkring 60 minutter. For å få en mest mulig åpen diskusjon om temaet ble ungdommene ikke presentert for ulike eksisterende forståelser eller definisjoner av begrepene rasisme og diskriminering. Fokusgruppeintervjuene ble igangsatt med spørsmål som: Hva tenker dere når jeg sier ordet rasisme? og: Er det forskjell på rasisme og diskriminering? Ungdommenes diskusjoner tok ulike retninger i de ulike fokusgruppene, noe den åpne inngangen til fokusgruppeintervjuene la opp til. Min rolle ble i stor grad å stille oppfølgingsspørsmål knyttet til innspill fra ungdommene og kontrollspørsmål for å sikre meg at jeg hadde forstått det de sa riktig. Transkriberingen, og den begynnende analysen, foregikk parallelt med datainnsamlingen. Dette muliggjorde at jeg kunne trekke momenter som ble

5 To av deltakerne i denne gruppen har afrikansk bakgrunn, èn er fra Midt-Østen. Slik samtalen forløp kom det fram opplysninger som tyder på at de alle tre er flyktninger eller har innvandret til Norge på annen måte. 
tematisert i de tidlige fokusgruppeintervjuene inn i diskusjonene i de senere intervjuene. I meningsfortettingen som foregikk i analysen tegnet det seg noen sentrale tema jeg sorterte ungdommenes utsagn inn i. Flere av utsagnene kunne passe inn i flere av temaene, og temaene kunne henge sammen. Jeg har i analysen ønsket å avdekke om noen deltakere eller forståelser har vært førende og dermed fått sentral plass på andre deltakeres bekostning. Noen av ungdommene var mer aktiv enn andre, men alle ga hverandre rom til å bidra. Materialet kan ikke betraktes som representativt for hvordan ungdom generelt forstår rasisme og diskriminering. Studien gir kunnskap om noen ungdommers betraktninger og refleksjoner rundt temaet.

\section{Slik ungdom forstår det}

\section{Rasisme og diskriminering som både likt og ulikt}

For ungdommene som har deltatt i denne studien handlet rasisme og diskriminering om mye forskjellig. Ordene ble assosiert med forskjellsbehandling, undertrykkelse og negative holdninger til »den andre». Ungdommene formidlet forståelser av at rasisme og diskriminering er det samme og samtidig forskjellig. Følgende sitat er beskrivende for hvordan dette ble uttrykt: "Rasisme er en form for diskriminering. Hver rasistiske handling er en måte å diskriminere på, kanskje? « (Nils, gr. 1). ${ }^{6}$ Diskriminering forstås

6 Jeg har gitt ungdommene nye navn i presentasjonen av materialet. som noe mer eller bredere enn rasisme. Diskriminering kan i følge ungdommene skje på grunn av "den andres» annerledeshet. Ungdommene sa diskriminering kan skje på grunn av religion, kjønn, seksuell legning og funksjonshemming. Kvinnediskriminering så ut til å være et kjent begrep for dem. Om diskriminering skjer på grunn av for eksempel en persons hudfarge eller etniske opprinnelse, ble det fortsatt forstått som diskriminering. Men det kunne av ungdommene også kalles rasisme. Gjennomgående for deltakerne var at de knyttet rasisme til at mennesker utsettes for negativ forskjellsbehandling på grunn av hudfarge, etnisk opprinnelse eller navn. Noen var inne på at klær, språk, kultur og religion kan være bakgrunn for denne forskjellsbehandlingen. Ungdommene assosierte ordet rasisme med mobbing, undertrykkelse, intoleranse, fordommer og å »henge ut» noen. Ungdommene forsøkte å finne en grenseoppgang mellom begrepene rasisme og diskriminering. Men i diskusjonene ble begrepene i stor grad bruk og forstått om hverandre. Nils sitt "kanskje» i sitatet over kan også sees som et uttrykk for hvordan ungdommene formidlet at dette ikke var enkelt å formulere klart og entydig. Videre kan det stå som et eksempel på at ungdommene hadde en åpen refleksjon rundt temaet. De krevde ikke et "riktig» svar eller skarpe definisjoner fra seg selv eller hverandre.

Assosiasjonene ungdommene hadde til rasisme og diskriminering uttrykker at dette knyttes både til et holdningsaspekt og et handlingsaspekt. Forståelser av rasisme som holdninger kom til uttrykk gjennom utsagn som "Rasisme har med tankene à gjøre "(Nancy, gr. 4) og "Jeg tenker mest for- 
dommer. At folk kanskje ikke er så direkte mot innvandrere. Men at det er mer sånn egne holdninger, som jeg ikke trenger å si (Janne, gr. 2). Janne formidlet her en umiddelbar forståelse av rasisme som fordommer. Sitatene over kan isolert sett tolkes som forståelser av rasisme som et holdningsfenomen. Men sett i sammenheng med andre uttalelser i løpet av intervjuene tegner det seg et bilde av at rasisme ikke forstås som enten et holdnings- eller et handlingsfenomen, men som en kombinasjon av disse. Noen av ungdommene var inne på at rasisme kan forstås som mer bevisst og kanskje mer målrettet enn diskriminering. De uttrykker med dette at holdninger kan ha betydning i deres forståelse av rasisme, men de var ikke eksplisitt opptatt av at det må ligge en negativ eller bevisst holdning bak det de forsto som rasistiske handlinger. I denne delen av materialet kan en se konturer av likhet med det tidligere nevnte omdreiningspunktet i norsk akademisk debatt, som har gått rundt vektleggingen av holdningers og handlingers betydning for forståelsen av rasisme. Ungdommenes diskusjoner og refleksjoner gikk imidlertid betydelig bredere enn dette.

\section{"Tydelig rasisme" og "rasisme du ikke ser"}

Ungdommene formidler at rasisme kan være mer eller mindre direkte uttrykt, og mer eller mindre synlig i samfunnet. De ga flere eksempler på hva de på ulike måter beskrev som synlig rasisme. Denne rasismen ble omtalt som "åpenbar", "direkte" eller srasisme $i$ stor grad «. Denne formen for rasisme ble eksemplifisert med at noen sier eller gjør noe nedlatende eller stygt direkte til en annen. Svein (gr. 1) fortalte om en situasjon han selv har sett.

Jeg var $i$ byen her en gang. Så kom det to negre forbi og en stor skinhead som så litt smånazi ut. Han var veldig full. Han begynte å le og peke og si; se apekattene. Det er ganske tydelig rasisme, mener jeg da.

Det er flere aspekt ved denne situasjonen som gjør at ungdommene vil kalle dette tydelig og direkte rasisme. Mannen som Svein beskrev som skinhead sa "se apekattene" direkte til de to andre. Ytringen ble ikke forsøkt skjult og det som ble sagt oppfattes som nedlatende uttrykk og kanskje som skjellsord. I tillegg lo mannen da han sa det. Han kommuniserte et følelsesuttrykk. Å le av andre, og samtidig å peke på noen anses som dårlig folkeskikk, som brudd på sosiale ritualer. Svein beskrev mannens utseende ved å kalle ham »skin head", og han la til at denne mannen "så litt smånazi ut«. Dette uttrykker hvordan mannens utseende gjorde at Svein så ut til å anta at mannen hadde negative holdninger til fargede mennesker. En antagelse om at det lå en holdning bak handlingen ble dermed gitt vekt i fortolkningen av dette som rasisme. Kombinert med mannens tydelighet i sitt uttrykk og at han kommuniserte et følelsesuttrykk, kan forståelsen av denne situasjonen som rasisme sies å være analog med Liens (1997a, 1997b) forståelse. Lien argumenterer for en smal og tilnærmet klassisk forståelse av rasisme. Hun formidler at en situasjon kan forstås som rasistisk om det foregår en ekskluderende 
handling hvor utøveren av handlingen har en ekskluderende intensjon, et negativt bilde av den andre, og at handleren har et sterkt og hatefullt affektivt uttrykk. "Det er følelsen (hatet) som - når alt kommer til alt - kjennetegner rasismen", skriver Lien (1997b s. 30). Hun argumenterer for en forståelse hvor holdningen og intensjonen gis avgjørende betydning for å unngå at rasismebegrepet blir forvirrende. Hun hevder begrepet mister sin kraft om det brukes om for mange fenomen. Momentene ungdommene la vekt på i sin forståelse av den situasjonen Svein beskrev som rasistisk er tilsynelatende lik Liens argumentasjon. Men med Liens vektlegging av en intensjon om å ekskludere og av et negativt bilde av den andre kan den beskrevne situasjonen falle utenfor hva Lien (ibid.) forstår som rasisme. I sin beskrivelse sa ikke Svein noe om den fulle mannens intensjon, trolig fordi den ikke kom eksplisitt til uttrykk. En kan også stille spørsmål om mannens latter kan betegnes som et sterkt og hatefullt affektivt uttrykk. Dette synliggjør hvor sterke krav Lien stiller i sin forståelse av rasisme.

Noen av ungdommene hevdet at det finnes mest av "rasisme du ikke ser " (Mona, gr. 2). I motsetning til beskrivelsen av den tydelige rasismen, ble dette beskrevet som forskjellsbehandling som kan gis forklaringer slik at handlingen ikke framstår som rasistisk. Handlinger "som det finnes unnskyldninger for", som Janne (gr. 2) uttrykte det. ${ }^{7}$ Eksempler de ga var at mennesker som ikke har hvit hudfarge kan miste muligheten til jobb eller skoleplass på grunn av hud-

7 Understreking av ord i sitat viser deltakerens trykk på ordet i sitt utsagn. fargen sin. Det er rasisme som ikke vises i samfunnet, sa ungdommene. Denne måten å forstå uusynlig" rasisme ligger nært opp til det Høgmo (1998), i sin komparative studie av innvandreres opplevelse av inkludering og ekskludering i det norske samfunn, kaller usynlig diskriminering. På samme måte som ungdommene, er Høgmo opptatt av at forskjellsbehandling kan foregå uten at en tredjepart ser det. ${ }^{8}$ Ungdommene er inne på at den usynlige rasismen også kan være skjult for den som utsettes for den. Lene (gr. 3) uttrykte det slik:

At du mobber en person for et eller annet, og at grunnen for at du gjør det er at personen er annerledes enn deg, er svart eller noe. Men den personen du gjør dette mot, den svarte, vet ikke at det er derfor. Fordi du sier ikke noe om det.

Nancy (gr. 4) formidlet at hun opplever å bli behandlet "annerledes", uten å vite hvorfor. Hun kan ha et ledig sete ved siden av seg $\mathrm{i}$ en ellers full buss, men ingen kommer og setter seg ved siden av henne. "Noen skal heller stå enn å sitte ved siden av meg", sa hun. Hun visste ikke hvorfor det var sånn, men tenkte at folk kanskje trekker seg unna fordi hun er svart; «Det er vanskelig å vite, men det er sånn "(Nancy, gr. 4). Denne uttalelsen kan sies å bekrefte Lenes antagelse om at det ungdommene kalte den usynlige rasismen også kan være usynlig for den personen handlingen er rettet mot, i den betyd-

8 Høgmo (1998 s. 23) velger å wreservere seg« mot rasismebegrepet. Han begrunner dette med at han ikke ønsker at begrep, men informantenes fortolkninger skal gis hovedfokus. 
ning at den som opplever seg forskjellsbehandlet ikke vet hvorfor det skjer. Det blir også, som Høgmo (ibid.) skriver, usynlig for tredjeperson.

Som beskrevet tidligere brukte flere av ungdommene begrepene rasisme og diskriminering om hverandre. Flere av de hvite ungdommen var usikre på og ikke så opptatt av hva som skulle benevnes som det ene eller det andre. Aisha, Nancy og Rebeca i gruppe 4 var mer klar på dette. I løpet av fokusgruppeintervjuet beskrev de en rekke episoder som de mente er rasisme.

Vi er ikke flinke til å snakke norsk også noen ganger nair vi snakker, noen av de norske bare ler, nair du uttaler feil (Rebeca, gr. 4).

Jeg har opplevd mange ungdommer som slär meg med stein og som roper; Hvorfor har du på deg sånn skjerf, og sånn (Aisha, gr. 4).

Jeg har voert på butikken og på Narvesen. De som sitter $i$ kassa, alle sier; Hallo, voersågod. Men når jeg kommer... (Viser med kroppen hvordan kassadama blir stille og ser ned, håndterer varene) Nå jeg kommer, så ingenting (Nancy, gr. 4).

Dette er situasjoner med ulik grad av alvorlighet og tydelighet. Men Aisha, Rebeca og Nancy mente alt dette er rasisme. ${ }^{9}$ De argumenterte med at alle disse situasjonene handler om negative måter å bli forskjellsbehandlet på. "Vi blir ikke behandlet som nordmenn. Det er rasisme» sa Rebeca (gr.

9 Se Prieur (2004 s. 119) for en redegjørelse av to ulike tendenser hun mener å se som reaksjon på opplevd rasisme og diskriminering.
4). Disse ungdommenes uttrykk for at deres opplevelser kan betegnes som rasisme, kan de finne støtte for hos Gullestad (2000, 2002) og Lunde (1997). De er begge opptatt av at handlingers ekskluderende konsekvenser og den utsattes opplevelse må tillegges avgjørende betydning for hvorvidt handlinger skal beskrives og benevnes som rasistisk. Ett argument er at det er effekten av handlingen, og ikke intensjonen eller holdningen bak handlingen, som er av betydning for den som er utsatt. Et av Gullestads (2002) ankepunkt mot smale forståelser av rasisme, er at intensjonen bak en handling kan være vanskelig tilgjengelig for andre personer i situasjonen, og for samfunnet. Noe som kan bidra til å usynliggjøre rasisme som fenomen, hevder hun. Ungdommenes uttalelser som er vist over belyser både det at intensjon bak en handling kan være vanskelig tilgjengelig, og kommuniserer en forståelse av at rasisme og diskriminering kan forekomme mer "usynlig». Gulllestad (ibid.) og Lunde (ibid.) argumenterer for brede forståelser av rasisme fordi en med det tar den utsattes perspektiv. De som opplever seg utsatt vil dermed gis definisjonsmakt over situasjonen. $\AA$ inneha definisjonsmakt kan gi en opplevelse av kontroll i situasjoner og i livet. Ved å ikke ha en slik kontroll kan mennesker oppleve avmakt, hevder Gullestad (ibid.). Hun skriver: „En måte å være avmektig på er å mangle kontroll over eget liv og bekreftelse på egen verdighet" (2002 s. 143). For Gullestad kan det å miste denne kontrollen og verdigheten være konsekvenser av rasisme. Lundes (ibid.) og Gullestads (ibid.) agenda ligger imidlertid utover en debatt om kun begrepsdefinisjoner og begrepsbruk. De 
formidler et behov for mer refleksjon rundt ekskluderingsprosesser. For Lien (1997a) vil det ungdommene i gruppe fire her formidlet som rasisme trolig være eksempler på hvordan rasismebegrepet blir for altomfattende og kraftløst, og derfor ikke bør brukes.

I motsetning til Aisha, Rebeca og Nancys oppfatning om at "alt dette" er rasisme, sa Svein (gr. 1): "Det må ganske ekstreme tilfeller til for at det skal voere ren rasisme, mener jeg. At det ikke er noe annet som ligger bak". Denne uttalelsen uttrykker en smalere forståelse enn at "alt" kan kalles rasisme. Sveins sitat antyder at i situasjoner utover denne "rene rasismen" kan det være andre forklaringer på den forskjellsbehandlingen som skjer. Det Svein her omtalte som forklaringer, vil kanskje bli forstått som "unnskyldninger" for forskjellsbehandling av Janne (gr. 2). Som vist tidligere antok hun at rasisme kan usynliggjøres gjennom å unnskylde handlinger.

\section{For noe du gjør, eller for noe duer}

Ungdommene ser ut til å sette et skille mellom det å bli forskjellsbehandlet for noe en person er og å bli forskjellsbehandlet for noe personen gjør. Dette kommer til uttrykk blant annet i en diskusjon rundt negative holdninger til eller utsagn om polske arbeidere i Norge. I diskusjonen ble det formidlet en usikkerhet rundt hvordan dette skal forstås, gjennom uttalelser som: "Da er det jo samme farge, de ser jo like dan ut" (Jonas, gr. 2) og "Men der har det kanskje ikke så mye med kultur å gjøre"(Berit, gr. 2). Utsagnene kan tolkes som at polakkers annerledeshet ikke kan forklares med husfarge eller kulturell forskjell. Fra ungdommenes diskusjon kan det se ut til at de mener at negative bilder av og utsagn om polakker i Norge ikke kan forstås som diskriminering eller rasisme. Blant annet fordi de negative bildene og holdningene er knyttet til noe polakkene gjør, "de tar jobbene" (Jonas, gr. 2). Tilsvarende budskap uttrykkes i følgende sitat: "Jeg mener det er diskriminering når du rakker ned på noen på grunn av noe de er" (Svein, gr. 1). Følgelig vil forskjellsbehandling som er knyttet til noe den andre gjør, ikke bli forstått som rasisme eller diskriminering. De negative bildene eller holdningene forstås da som en konsekvens av det som gjøres.

I en av gruppene spurte jeg om kvinner med hijab sine problem med å få jobb kan kalles diskriminering. Fra gruppens diskusjon rundt dette kom forståelser av hva som er ansett som naturlig og normalt til uttrykk. I tillegg aktualiseres hvordan symbol får betydning for fortolkning. Goffman (2000) hevder at alle samfunn har regler for hva som skal anses som vanlig og naturlig for mennesker innenfor ulike kategorier. I den ovenfor nevnte diskusjonen kom det til uttrykk at det å bære det muslimske hodeplagget hijab som ansatt $i$ for eksempel en butikk eller i en hotellresepsjon, ikke ble ansett naturlig eller normalt. Ungdommene uttrykte tvil til at kvinner med hijab vil vekke tillit eller oppfattes å ha relevant kompetanse i rollen. "Det går en grense ved ting som er ekstremt, da. Som for eksempel ansiktet fullt av tatoveringer eller hijab eller stort gult hår" (Svein, gr. 1). Tatoveringene, det 
gule håret og hijaben presenteres her som ekstreme symbol som tillegges betydning $i$ fortolkningen.

Du skal voere en person det er enkelt å bare gå bort til og prate med uten problemer. Men du ser en person som er annerledes så skiller de seg veldig ut sånn, da kan du tenke, nei, du vet ikke helt hvordan du skal forholde deg til den personen, fordi at du fär andre tanker om den og da............ Det kan voere vanskelig (Nils, gr. 1).

Her uttrykkes forståelser av at symbolene den ansatte bærer kan bidra til å skape avstand mellom kunde og ansatt. Det som anses som unaturlig annerledeshet hos mennesker kan dermed skape usikkerhet i samspill med andre. Ungdommene formidlet at det å ha tatoveringer $\mathrm{i}$ ansiktet, hijab eller gult hår var måter å være annerledes på som kan endres, ved at symbolet som tillegges vekt tas bort. Det å bære symbolene som ungdommene trakk fram i diskusjonen, ble dermed forstått som noe personene gjør. Med dette uttrykte de at det ikke kunne kalles diskriminering om personer med tatovering i ansiktet eller med hijab ikke får innpass i arbeidsmarkedet. De ser en »logikk«(Svein, gr. 1) i det.

I forlengelse av ungdommenes refleksjon rundt det å voere og det å gjøre, kan det her være verdt å dvele ved tolkningen av kvinners bruk av hijab. Er dette noe kvinnene gjør eller er det et uttrykk for noe de $e r$ ? En kan forutsette at kvinner bruker hijab som et uttrykk for noe de er. Kvinnene uttrykker også hva de er. De er muslimske kvinner. Kanskje det er det sentrale her? Nordmenn og andre innbyggere i Vesten har de siste tiårene i økende grad blitt negative til muslimer (Fenton 2006, Ålund 2007, Schierup 1993)..$^{10}$ Etter angrepet på World Trade Center i USA 11 september 2001, bombeangrepet i London i 2005 og reaksjoner på trykkingen av Mohammed-tegninger i Skandinaviske aviser i 2006 og 2008, er denne negative holdningen også blitt til frykt hos mange. Noen av ungdommene i min studie var inne på dette. De ga uttrykk for en opplevelse av at nordmenns holdninger til muslimer er blitt mer negative de siste årene. Mona (gr. 2) sa: "Jeg mener at ofte så er den rasismen vi har $i$ dag, så går det veldig mye på religion«. Monas utsagn ble fulgt opp av Berit (gr. 2): "Ja. For det er muslimer som er verst i våre øyne, på en måte». Ungdommene trodde det negative bildet av muslimer og islam henger sammen med hva som presenteres i mediene om krig, kvinneundertrykkelse og uro.

Men det er jo det vi fär se av Iran og Irak og Pakistan og sånn. Vi fär se gevaer og vi fär se sinte menn som dreper. Vi fär jo ikke sett kulturen deres (Berit, gr. 2).

Sjelden at vi fär vite noe positivt og liksom om hverdagen. Vi hører bare om kvinnediskriminering og krig og bombing og sainn (Mona, gr. 2).

Dette aktualiserer et tilleggsaspekt til ungdommenes diskusjon om skillet mellom forskjellsbehandling for noe personer er og noe personer gjør. Vurderinger ungdom-

\footnotetext{
10 Steve Fenton, professor i sosiologi ved Universitetet i Bristol, under foredrag ved Høgskolen i Sør-Trøndelag, AHS, PSU, 16.11.06.
} 
mene gjorde i forhold til dette kan ha vært påvirket av deres forståelse av hva personene er.

\section{Relasjonelle forståelser}

Ungdommenes refleksjon rundt og beskrivelse av rasisme og diskriminering viser at dette forstås som relasjonelle fenomen, noe som i materialet kom fram på flere måter. Relasjonen mellom den som ytrer eller handler og den som ytringen eller handlingen er rettet mot er av betydning for hvordan situasjonen forstås av ungdommene. Overfor personer en ikke kjenner skal en være forsiktig med hva man sier. Fridas (gr. 1) sitat er beskrivende for hvordan ungdommene uttrykte dette: "For $d u$ går jo ikke og slenger rundt deg med kommentarer til hvem som helst. Det er gjerne til venner eller folk du kjenner.. Sitatet illustrerer også at i en vennerelasjon er mer tillat. Dette er flere av ungdommene inne på. Men det å kjenne hverandre er ikke tilstrekkelig. Følgende sitat belyser at en i tillegg må kjenne hverandres grenser og ha en felles forståelse av de begrep som brukes: "Når en er med venner, så vet en om en tar seg noer av det eller ikke. Og da vet også personen som tar det imot om den personen som sier det mener det negativt " (Lena, gr. 3). Et eksempel på hvordan ungdommene reflekterte rundt relasjonenes betydning, finner vi i en diskusjon i en av gruppene. Ungdommene i gruppen refererte til en felles venn som har foreldre fra Afrika og selv er svart. De sa at gutten ikke tar seg nær av at de, som er hans venner, sier neger til ham. Det er fordi de vet han synes det er greit. ${ }^{11}$ Om de har kunnskap om at det samme ordet representerer noe negativt for en annen, skal det ha betydning for hva de kan si, også i en vennerelasjon: „Om jeg hadde voert noer venn med en neger som faktisk tar seg noer av det, så hadde jeg ikke sagt det" (Lena, gr. 3). Relasjonen og kunnskapen om hverandres forståelse av begrep gis derfor betydning for hvilke innhold ord som brukes får. Videre sa ungdommene at deres venn ikke ville akseptert at en person som ikke kjenner ham hadde sagt neger til ham. "Da hadde det gått veldig galt" (ungdom, gr. 3). ${ }^{12}$ På denne måten formidlet ungdommene hvordan relasjonen tillegges betydning for tolkning av samhandling og innhold $i$ begrep. Om vi ser tilbake på episoden som Svein (gr. 1) beskrev om den fulle mannen som pekt og sa "se apekattene» om to svarte personer på gata, kom også der relasjonens betydning til uttrykk. I forlengelsen av beskrivelsen av situasjonen sa Svein: "Ja, og at han ikke kjenner dem heller«. Høgmo (1998) understreker betydningen av å se diskriminering som relasjonelle fenomen. Hans studie viser at mennesker med ulik etnisk bakgrunn opplever diskriminering ulikt fordi opplevelsen er

11 Gutten denne vennegruppa omtalte var ikke med i fokusgruppeintervjuet. Om han synes negerbegrepet er greit eller ikke kommer derfor ikke til uttrykk. At vennegjengen oppfatter at de kan bruke negerbegrepet trenger ikke bety at han synes det er greit. For gutten kan det å beholde vennerelasjonene være av større betydning enn å gjøre vennene oppmerksom på hva som kan oppleves ubehagelig eller krenkende. Det kan være utfordringer knyttet til å si ifra, noe jeg kommer tilbake til senere i artikkelen.

12 Av lydopptaket av fokusgruppeintervjuet var det vanskelig å høre hvem av ungdommene som sa dette. 
avhengig av hvem innvandreren er som "sosial trafikant"(ibid. s. 203), hvilke arena innvandreren ferdes på og hvem innvandreren møter. Opplevelsene og erfaringene er også kjønnsavhengig, skriver han. ${ }^{13}$ Min studie bekrefter dermed Høgmos funn, og en kan si at den tilfører nyanser til en relasjonell forståelse av rasisme og diskriminering, gjennom å vise hvordan felles forståelser for begrepsbruk og kjennskap til aktørers grenser i en interaksjon får betydning for forståelsen av situasjoner som krenkende eller ikke.

Ungdommene formidlet at ord som "hore", "faen ta deg" og "joevla neger "brukes i ungdommenes språk, uten at de nødvendigvis legger noe spesielt $i$ ordvalget. Flere var derimot inne på at ordet neger kan være et potensielt krenkende ord. "Neger er et skjellsord som mange bruker. Jeg tar det som veldig negativt og alt, mens andre ser på det som, ja det har jo ikke noe å si «(Berit, gr. 2). Materialet viser at ungdommene har ulikt syn på og formidler et noe ambivalent forhold til ordet neger. Noen var klart ikke komfortable med å bruke eller høre ordet. "Men jeg synes også at det er ekkelt å si det ordet" (Mona, gr. 2). Mens andre synes det er et greit ord.

\section{Hvisjeg sier neger til en neger så kan han opp-} fatte det som särende, men ordet neger er jo et helt vanlig ord $i$ dag, egentlig. Som ikke menes noe sårende når folk sier det. I vertfall ikke somjeg oppfatter det, da (Svein, gr. 1).

Jeg synes at om en ikke kan si det så synes jeg en legger opp til at det er noe galt $i$ å voere det på en måte...... Det betyr jo å voere mørk (Janne, gr. 2).

13 Se også Prieur (2002).
Fra disse sitatene kan en blant annet lese en forståelse av at begrepet neger kan ha hatt andre konnotasjoner tidligere. I sitatene formidles det også at ungdommene antar det ikke ligger noen negativ betydning $\mathrm{i}$ ordet lenger. Janne sa imidlertid senere at ordet neger ikke alltid kan brukes. Her kom både en ambivalens til ordet til uttrykk og igjen ble relasjonelle forståelser formidlet.

Det er litt interessant det at man kan........Jeg føler meg ikke slem omjeg sier; Han negeren itredje. Men; hei, er du negeren i tredje. Da, da blir det noe annet (Janne, gr. 2).

Til dette sa Berit (gr. 2): Men dablir det jo et ladet ord när du ikke kan si det til en person. Da betyr det jo at det blir en fornoermelse.

Debatter om negerbegrepet er ikke nye i norsk kontekst. Idrettsutøveren John Ertzgaard igangsatte en "negerdebatt" som gikk vinteren 2000-2001 (Gullestad 2002). I desember 2006 oppsto den på nytt da det ble kjent at NRK-barnetimen hadde besluttet å bytte ut ordet neger med andre ord i fremtidige produksjoner av opplesning og dramatisering av barnelitteratur. ${ }^{14}$ Astrid Lindgrens historie om Pippi og Torbjørn Egners sang „Visen om vesle Hoa» ble sentrale i denne debatten..$^{15}$ I tillegg til å bli en debatt om å endre åndsverk

14 Barnetimen er et barneprogram på NRK-radio. Programmet har lang tradisjon og kan betraktes som en sentral institusjon innen kulturformidling til barn.

15 NRK hadde besluttet at Pippis pappa i framtidige produksjoner skal omtales som sydhavskonge og ikke negerkonge, slik det opprinnelig ble skrevet. Hjeltnes i VG 11.12.06, Børja i Dagbladet 07.12.06, Oterholm i NRK 07.12.06.

Gunnhild Vist: Rasisme og diskriminering: komplekse... 
ble dette en debatt om ordet neger. Ordskiftet gikk om hva negerbegrepet betyr, hvorvidt det er et nøytralt ord i det norske språket og at det ikke menes som negativt å bruke det, selv om det for andre har en negativ konnotasjon. ${ }^{16}$ Flere var også opptatt av at barn ikke tar skade av eller blir rasister av å høre ordet neger. ${ }^{17}$ Ungdommene løftet selv diskusjonene om ordet neger fram i sine fokusgruppeintervju, noe som belyser ordets aktualitet i forhold til diskusjoner rundt rasisme og diskriminering. Også sangen om Hoa ble trukket fram $i$ en av gruppene, som en assosiasjon da de diskuterte negerbegrepet. De nynnet litt på sangen og mente måten afrikanere ble beskrevet i sangen var lik måten media formidler et naivt bilde av afrikanere. At ungdommene trakk fram barnelitteratur i sine diskusjoner viser hvordan bilder denne litteraturen har formidlet utgjorde en del av ungdommenes fortolkningsramme. Fokusgruppeintervjuene hvor negerbegrepet og sangen ble løftet fram ble gjennomført flere måneder før debattene startet i media i desember 2006. Ungdommenes diskusjoner rundt negerbegrepet er på den måten nyttig både som eksempel på deres uttrykk for relasjonelle forståelser, og de belyser ordet neger sin spesielle plass i debatter knyttet til rasisme og diskriminering.

\section{Si ifra, så vil vi si unnskyld}

Noen av ungdommene sa at det er lett å

16 Debattprogrammet Standpunkt på NRK 1 19.12.06 er et eksempel på hvordan ordskiftet i debatten gikk. Se også Sollund (2007).

17 Vinje i Dagbladet 06.12.06 og Hjeltnes i VG 11.12.06. gjøre feil, og de uttrykte en frykt for å bli misforstått. Følgende to sitat, som kom relativt nært i ett av fokusgruppeintervjuene, illustrerer dette: "Det er vanskelig å vite hva en skal si, ja. Og det er mye som er tabu» (Janne, gr. 2) og "Man blir litt redd for å voere rasistisk" (Mona, gr. 2). Usikkerhet på hvordan "den andre« vil reagere på ens utsagn ser ut til å være av betydning. Frykten for å bli kalt rasist har hindret folk fra å delta i debatter om innvandring og integrering, hevder Brox (1991). I følge Hagelund (2004) hevdes det også at denne frykten har hindret utviklingen av en god innvandringsog integreringspolitikk. I tråd med dette hevder Lien (1997a, 1997b) at en slik frykt kan skremme folk fra å løfte fram problematiske tradisjoner og praksiser blant innvandrere. Blant ungdommene ble det imidlertid uttrykt en tro på at det er mulig å oppklare feiltrinn. "Selvfølgelig kan alle gjøre en feil en gang og si noe en ikke skulle sagt. Men det er også lov å si unnskyld etterpå (Frida, gr. 1). Frida gjentok dette flere ganger i løpet av intervjuet, og andre var inne på det samme. De ser ut til å mene at den som tråkker feil bør, og vil, beklage feilen overfor den andre. Den utsatte gis dermed makt til å definere situasjoner som krenkende, rasistisk eller diskriminerende, noe blant andre Gullestad (2002) og Lunde (1997) er opptatt av. Samtidig tillegges den som opplever seg krenket eller utsatt for forskjellsbehandling et ansvar for å si ifra. Definisjonsmakten og ansvaret trenger imidlertid ikke være lett å forvalte. "Men vi også er redd for å snakke til dem, det er en ting. For de hører ikke på oss. Vi er ikke bare redde, men hva er vitsen? Ingen skal gjøre noe med det“ (Nancy, gr.4). Her formidlet Nancy erfaring med at det 
kan følge en risiko med å si ifra om en opplever seg urettferdig behandlet. Aisha (gr. 4) fortalte om tilsvarende erfaring fra en gang hun og mannen skulle fylle bensin på en bensinstasjon. De hadde stoppet bilen og løftet ut bensinpumpa da "en norsk stor mann « kom bort til dem og sa: "Hei, pakkis, meg først . Aishas mann hadde blitt veldig sint, men de hadde satt seg i bilen og ventet til nordmannen var ferdig, og så fylt bensin. Her aktualiseres at det å "ta igjen" eller si ifra blir vanskelig, av flere grunner. En faktor var at de fryktet den "norskes" reaksjon. Videre formidlet Aisha en frykt for å bli stående igjen uten støtte fra andre på at noe urettmessig var skjedd. Slike bekymringer ble formidlet også av de andre gjennom erfaringer med at myndigheter, politi eller andre ikke bistår om de sier ifra. ${ }^{18}$

Denne delen av materialet løfter fram maktaspekt og grunntanker knyttet til anerkjennelse. Ifølge Taylor (1994) trenger mennesket, som grunnleggende dialektisk, anerkjennelse fra andre for å kunne utvikle sin identitet på en god måte. Han hevder at det å ikke få anerkjennelse kan være en form for undertrykkelse, ved at mennesker tvinges inn i vanskelige og innskrenkete posisjoner i tilværelsen. Aisha og Nancys eksempler over viser hvordan de har mislyktes i å få anerkjennelse, både som menneske og for å ha blitt urettmessig behandlet. Fra utsatte posisjoner kan det derfor bli vanskelig å be om anerkjennelse igjen. De ungdommene som ba om å bli gjort oppmerksom på feil de gjør, ser ut til å ikke ha reflektert over det ulikeverdige maktforholdet som kommer

18 Se også Buntu (2001), Kvam (2001) og OMOD (2006). til uttrykk her. De formidlet en intensjon om å gi anerkjennelse, men ser ikke ut til å være klar over at denne intensjonen endres til et krav, tatt de ulike maktposisjonene $i$ betraktning. Majoritetsbefolkningens forventning om å bli gjort oppmerksom på at noe oppleves krenkende, trenger dermed ikke å bli imøtekommet.

Som vist tidligere henger ungdommene i gruppe fire sine forståelser av rasisme nært sammen med erfaringer de har hatt. De formidlet opplevelser av å bli oversett, satt til side, mistenkeliggjort og en følelse av utrygghet. Slike opplevelser finner også Høgmo (1998) blant informanter i sin studie. Å overse, sette til side eller mistenkeliggjøre kan være måter å kommunisere ikke-anerkjennelse, eller ringakt, som Høgmo (ibid.) kaller det. Høgmo skriver at en strategi som personer som opplever seg utsatt for "etnisk ringakt» (ibid. s. 11) velger, er å unngå å oppsøke steder hvor de har hatt slike opplevelser eller antar at dette kan skje. En slik strategi beskrives også i mitt materiale. Nancy (gr. 4) uttrykte det slik: "Jeg blander meg ikke med nordmenn. Jeg går ikke et sted hvor jeg føler at jeg blir behandlet forskjellig fra andre". Her kommer det ikke fram hvilke steder som unngås. Sitatet viser imidlertid at samme strategi som Høgmo (ibid.) beskriver, tas i bruk av ungdommer jeg intervjuet. Nancys mulighet til å delta på flere av samfunnets ulike arenaer blir begrenset. Hennes sitat er dermed beskrivende for hvordan ikkeanerkjennelse eller "mis-anerkjennelse» (Taylor 1994 s. 37) kan være en form for undertrykkelse, gjennom at mennesker settes i innskrenkende posisjoner. 


\section{Avsluttende refleksjoner}

Ungdommenes uttrykk for sine forståelser av rasisme og diskriminering synliggjør at dette er komplekse tema. Med brede penselstrøk kan en si at rasisme og diskriminering forstås som noe likt, men samtidig forskjellig. Ungdommene formidler at dette er fenomen som handler om ulike former for negativ forskjellsbehandling som inneholder både et holdningsaspekt og et handlingsaspekt. Rasisme og diskriminering ble beskrevet og omtalt som tydelig, og som mer usynlig. Et spennende aspekt ved materialet er hvilken betydning aktørers relasjon blir gitt i forståelsen av både situasjonen aktørene er i, og av hvilke begrep som kan brukes. De mange fasettene som kommer til uttrykk synliggjør at det i materialet ikke framkommer forståelser og beskrivelser av kun én rasisme. Det kan derfor være mer hensiktsmessig å snakke om ulike rasismer. ${ }^{19}$ Ungdommenes innspill gjenspeiler mange av posisjonene i den norske akademiske debatten om begrepene. Men som artikkelen har vist gikk ungdommenes diskusjoner i mange retninger og ut over sentrale tema i den akademiske debatten. Det komplekse bildet som tegnes i studien bidrar til å sette fokus på at debatter om rasisme og diskriminering i større grad bør løfte fram at dette forstås svært ulikt. Det er behov for stadige refleksjoner rundt begrepene. Ikke med det mål å finne begrepsforståelser eller definisjoner alle kan bli enige om, men for å synliggjøre og tematisere hvordan begrepene fylles ulikt. Hva vil det bety for diskusjonene om disse temaene om fokus

19 Se også Gullestad (2002) og Fangen (1997). flyttes fra å rydde opp i uklarhet til å se nærmere på ulikhet?

I materialet kan en se konturer av at ordene og fenomenene rasisme og diskriminering kan ha forskjellig betydning for hvit og svart ungdom. For det første så de svarte ungdommene, i større grad enn de hvite, ut til å velge rasismebegrepet og kanskje forkaste diskrimineringsbegrepet. For det andre hadde ungdommene ulik nærhet til temaet. Det kom blant annet til uttrykk ved at de svarte ungdommene i stor grad formidlet sine forståelser ved å fortelle om personlige erfaringer. Sammensetningen av fokusgruppene kan ha hatt betydning for at disse ulikhetene kom til uttrykk, i og med at de hvite og de svarte ungdommene diskuterte i hver sine grupper. Med grupper bestående av både svarte og hvite ungdommer kunne studien fått fram andre refleksjoner og forståelser. I videre studier om forståelser av rasisme og diskriminering kan det være interessant å se på hvordan ulike måter å sette sammen fokusgrupper på kan frambringe ytterligere nyanser $i$ det bildet som her er tegnet. Det kan også være av interesse å se nærmere på konturene av at ordenen og fenomenene ser ut til å ha ulik betydning for svart og hvit ungdom.

Forskning på og debatter om begrepene rasisme og diskriminering vil imidlertid ikke være nyttige alene. Studien aktualiserer at det i tillegg er behov for å bringe inn nye teoretiske perspektiver. I videre kunnskapsutvikling vil det være viktig å supplere diskusjoner om begrepsbruk og definisjoner med analyser knyttet til makt, anerkjennelse og krenkelse. Innledningsvis viste jeg til Hagelund (2003, 2004) og Fangen (1997) som hevder at begrepet rasisme har gene- 
rert debatter som er blitt preget av moralsk retorikk. Nye teoretiske blikk kan få debattene på nye spor. Ungdommene i studien kommuniserer ønsker om å leve anstendige liv i et flerkulturelt samfunn. Men som ungdommene selv er inne på ligger det utford- ringer her. På tross av intensjon om å leve anstendig kan utfallet bli eksklusjon og krenkelse. Med teoretiske perspektiver om makt og anerkjennelse kan det bli mulig å gå inn i dette feltet og utvikle ny kunnskap.

\section{Referenser}

Brox, Ottar (1991) "Jeg er ikke rasist, men...." Hvordan får vi våre meninger om innvandring og innvandrere? Oslo: Gyldendal Norsk Forlag.

Buntu, Amani Olubanjo (2001) „Når du er så svart at alt bare blir sint». I Hadia Tajik (red.) Svart på hvitt. Oslo: Tiden Norsk Forlag A/S.

Fangen, Katrine (1997) Rasisme i plural form. Paradigmer og begreper om rasisme. Oslo: Universitetet i Oslo, Institutt for sosiologi og samfunnsgeografi, Rapport 1997: 7.

Goffman, Erving (2000 [1963]) Stigma: Om afvigerens sociale identitet. København: Gyldendals samfundsbibliotek.

Gullestad, Marianne (2000) „Blinde slaver av våre fordommeru. I Siri Meyer (red.) Avmakt: Skjebne, frigjøring eller maktbase? Oslo: Gyldendal Akademisk.

Gullestad, Marianne (2002) Det norske sett med nye øyne: Kritisk analyse av norsk innvandringsdebatt. Oslo: Universitetsforlaget.

Hagelund, Anniken (2003) The Importance of Being Decent: Political Discourse on Immigration in Norway 1970-2002. Oslo: Unipax.

Hagelund, Anniken (2004) "Anstendighetens utside: 'Rasisme' i norsk innvandringspolitisk diskurs". Tidsskrift for samfunnsforskning vol $45 \mathrm{nr} \mathrm{1,} \mathrm{s.} \mathrm{3-29.}$

Høgmo, Asle (1998) Fremmed i det norske hus: Innvandreres møte med bygdesamfunn, småby og storby. Oslo: Gyldendal Norsk Forlag.

Kvam, Hannah Wozene (2001) "Svart pepper». I Hadia Tajik (red.) Svart på hvitt. Oslo: Tiden Norsk Forlag A/S.
Lien, Inger-Lise (1997a) Ordet som stempler djev lene. Oslo: Aventura.

Lien, Inger-Lise (1997b) "Hvordan diagnostisere rasisme?". I Ottar Brox (red.) De liker oss ikke: Den norske rasismens uttryksformer. Oslo: Tano Aschehoug.

LDO [Likestillings- og diskrimineringsombudet] (2008) Kartlegging av diskriminering $i$ statlig sektor-første trinn? Oslo: LDO.

Lunde, Henrik (1997) „Utenpå smiler jeg, men inni så brenner detw. I Ottar Brox (red.) De liker oss $i k k e$. Oslo: Tano Aschehoug.

OMOD [Organisasjonen mot Offentlig diskriminering] (2006) Pionerer i Norge. Ung, svart \& norsk. Oslo: OMOD.

Prieur, Annick (2002) „Fargens betydning. Om rasisme og konstruksjon av etniske identiteter". Sosiologi i dag vol. $32 \mathrm{nr}$ 4, s. 59-82.

Prieur, Annick (2004) Balansekunstnere. Betydningen av innvandrerbakgrunn i Norge. Oslo: Pax Forlag A/S.

Schierup, Carl-Ulrik (1993) På kulturens slagmark: mindretal og størretal taler om Danmark. Esbjerg: Sydjysk Universitetsforlag.

Sollund, Ragnhild Aslaug (2007) Tatt for en annen. En feltstudie av relasjonen mellom etniske minoriteter og politiet. Oslo: Gyldendal Akademisk.

Taylor, Charles (1994) Det mångkulturella samhället och erkännandets politik. Göteborg: Daidalos

Ålund, Aleksandra (2007) "Migration och socialt medborgarskap». Nordisk sosialt arbeid vol. 27 nr 4, s. 280-294. 


\section{Summary}

\section{Complexperceptions of racism and discrimination}

In Norway the terms racism and discrimination are used to describe a broad range of phenomena. The understandings and definitions of the terms are unclear. How these phenomena should be perceived is under debate. In this article I present different understandings of racism and discrimination among Norwegian youth, based on a qualitative study focusing on how young people perceive the terms. The discussions among the young people involved show that these are complex topics. Based on this study one can argue for the necessity to recognize that debates and studies concerning racism and discrimination in Norway need to reflect this complexity. In addition there is a need to include perspectives of power and recognition. 